\title{
AOR
}

Selected Papers of \#AoIR2021:

The 22nd Annual Conference of the

Association of Internet Researchers

Virtual Event / 13-16 Oct 2021

\section{THE AFFECTIVE BODY: PLATFORMED PRESENCE AND VIRTUAL EMBODIMENT IN THE POPULIST POLITICS OF NARENDRA MODI}

\author{
Laboni Bhattacharya \\ University of Southern California \\ Introduction
}

Political theory agrees that the charismatic leader's cult of personality is a cornerstone of populist politics, with an increasingly distrustful, contentious, and internally divided society seeing the leader as the embodiment of the popular will more viscerally than the electoral process allows (Laclau 2005). The power of the hypermasculine leader persists in the digital age where populists exert authoritarian control over media narratives and infrastructures, as feminist critiques of the iconography of statesmen like Putin, Erdogan and Duterte demonstrate (Chavez and Pacheo 2020). Yet this brand of strongman politics is discursively co-produced by the leader's physical presence; my presentation argues in contrast that Indian PM Narendra's Modi's affective body is animated by its persistent digitization, virtualization, and absence of liveness.

Modi's populism is driven by his appeal as a technocrat, a man accessible to the people via hologram, Twitter, exclusive apps, 3D modelled YouTube videos, and other digitally enabled forms of disembodied representation which create a "fantasy of unmediated access" (Govil and Baishya 2018). When Modi appears in public to perform yoga or lay a silver brick in the foundations of a temple, his corporeal form is one iteration of his virtualized, mediated persona. Modi's independence from the demands of embodiment is made possible by his substantive digital presence. The experiential intensity and interactivity of social media creates what I term "platform affect", which mobilizes affective discourses like nationalism to material effect, such as drawing large crowds galvanized by a sense of intimacy with Modi's virtual and physical person.

\section{Methods}

I conducted visual and textual analysis of video content, comments, and Twitter posts of Narendra Modi's "Yoga with Modi" series to observe the discursive construction of the "authentic" in his virtual yoga practice. I studied videos of Modi performing yoga in sourced from his Twitter account and observed the commentary on and recirculation of this content through memes, online news and WhatsApp forwards. I focused on identifying a subjective apprehension of the technocratic Modi persona. I situate my analysis in studies of South Asian visual culture (Jain 2021), Hindu nationalism and right-wing technoculture (Basu 2020, Govil and Baishya 2018), South

Suggested Citation (APA): Bhattacharya, L. (2021, October). The Affective Body: Platformed Presence and Virtual Embodiment in the Populist Politics of Narendra Modi. Paper presented at AolR 2021: The 22nd Annual Conference of the Association of Internet Researchers. Virtual Event: AolR. Retrieved from http://spir.aoir.org. 
Asian platform studies (Athique 2020) and nationalist affect and mobilization on social media (Mankekar 2015). While feminist scholars have studied the hypermasculinity and aggression of populist leaders, this paper explores the non-material and disembodied masculinity of the leader in a platformed society. Located specifically in India, this project also notes the uneven nature of platform access and regulation in a country where cheap smartphones and internet plans rapidly expand the digital public sphere without necessarily increasing political participation (Athique 2020). I further locate myself as a Hindu, upper-caste Indian woman whose social location is one highly privileged by right-wing Hindu nationalism.

\section{The Virtual Body of the Yogi: Maintaining Platformed Presence}

The interdependence of the corporeal and the virtual in the construction of charismatic presence is subject to specifically South Asian cultural registers of visuality and sociality. Modi's virtual persona is the result of the Bhartiya Janata Party's heavy investment in branding and PR campaigns, but its vocabulary is rooted in Indian modes of public conduct, such as that of the ascetic yogi, the chaste devotee of the nation, and the mahapurush ('great man'). These modes of being are legible and derive from popular remediations of masculinity in film, television, and public culture (Pathak and Perera 2018). Modi's legitimacy as a masculine paragon of restrained strength is driven by hypermediated events like the International Day of Yoga, which he proposed to the UN General Assembly a few months after taking office in 2014.

Modi's frequent tweets about yoga claim a lifetime of daily practice, establishing him as a yogi qualified to lead the nation on a path to rejuvenation and functioning as a springboard for the launch of his 2020 series of "Yoga with Modi" YouTube videos. In these videos, a 3D model of Modi guides YouTube viewers through a series of poses. His virtual body is aestheticized in its height, weight and flexibility, and the footage of the model is intercut with animated images of the musculoskeletal system informing the viewer of the body parts benefited by a particular stretch. In pre-COVID celebrations of Yoga Day, Modi made highly choreographed and often mocked appearances in mass demonstrations of yoga where he visibly struggled to model the competencies that his virtual body demonstrates. Yoga Day is part of a general UN mission of world health, but in India, the Modi administration has rapidly created state infrastructure that officializes yoga's role in disciplining unruly bodies and minds. The renativization of yoga is touted as an attempt to remind Indians of their national heritage and is closely linked to right-wing Hindu nationalist ideology and practice. (Alter 1997, Gupta and Copeman 2019).

\section{Findings}

This presentation focuses on the slippage between the virtual and the real bodies of the PM as a metonym for the overall "platformization" (Athique 2020) of the Indian political economy. Modi's promises of minimum government and maximum governance find realization in the supplementation of physical infrastructures with digital infrastructures, often at the cost of weakening public access. Yoga Day is part of the Modi government's push to redefine national health as self-discipline and self-discovery, 
yoked to Hindu nationalism. "Yoga with Modi" and Modi's Twitter discourse underscores this rhetoric of reclamation and self-empowerment. In official statements by Modi and his ministers, yoga is touted as nothing less than the cure to the ills of modernity, and an attempt at independence from the corrupting influence of Western culture. The virtual body of the leader reaps the privilege of dis-embodiment while delivering on populist claims to Hindu revivalism, the re-indigenization of yoga and authoritarian leadership.

\section{References}

1. Alter, Joseph. "A Therapy to Live by: Public Health, the Self and Nationalism in the Practice of a North Indian Yoga Society." Medical Anthropology 17, no. 4, 1997, pp. 309-335.

2. Athique, Adrian. "Platform Economy and Platformization". Platform Capitalism in India: Global Transformations in Media and Communication Research, ed. A Athique and V Parthasarathi. Palgrave Macmillan, 2020.

3. Basu, Anustup. Hindutva as Political Monotheism. Duke University Press, 2020.

4. Govil, Nitin, and Anirban Kapil Baishya. "The Bully in the Pulpit: Autocracy, Digital Social Media, and Right-Wing Populist Technoculture." Communication, Culture \& Critique, vol. 11, no. 1, Oxford University Press, 2018, pp. 67-84

5. Gupta, Copeman. "Awakening Hindu Nationalism through Yoga: Swami Ramdev and the Bharat Swabhiman Movement." Contemporary South Asia 27, no. 3, 2019, pp. 313-329.

6. Jain, Kajri. Gods in the Time of Democracy, Durham: Duke University Press, (forthcoming 2021)

7. Jeremy C De Chavez, and Vincent Pacheco. "Masculinity in the Age of (Philippine) Populism: Spectacle, Hypermasculinity, and Rodrigo Duterte." Masculinidades y Cambio Social, vol. 9, no. 3, Hipatia Press, 2020, pp. 261-83.

8. Laclau, Ernesto. On Populist Reason. Verso, 2005.

9. Mankekar, Purnima. Unsettling India: Affect, Temporality, Transnationality. Duke University Press, 2015. 